\title{
Ichnotaxonomy, functional morphology and paleoenvironmental context of Mesosauridae tracks from Permian of Brazil
}

\author{
Rafael Costa da Silva ${ }^{1}$, Fernando Antonio Sedor ${ }^{2}$ \& Antonio Carlos Sequeira Fernandes ${ }^{3}$
}

\begin{abstract}
Subaqueous vertebrate traces are fairly common in fossil record, but there are few studies on the theme due to the difficulties in classification and interpretation. In Brazil, subaqueous tracks were recorded in rocks of Irati Formation (Lower Permian, Paraná Basin). According to morphological features and interpretation, the ichnofossils were designated as a new ichnotaxon, Mesosaurichnium natans igen. nov. et isp. nov., and attributed to the activities of basal reptiles Mesosauridae. Based on faciology, the ichnofossils possibly were produced in a lower shoreface affected by storm waves and do not correspond to the original sedimentary surface, which was covered by a thin layer of crustacean shelly fragments during the production of the tracks. The tracks were produced by mesosaurids during the swimming next to the bottom with the long tail maintaining the propulsion. The mesosaurids were able to use the tail as the main propelling organ for fast swimming under undulatory propulsion, but with the paddle-like pedes acting as important accessory propellant during oscillatory propulsion, conferring greater maneuverability during slow swimming.
\end{abstract}

Keywords: subaqueous traces, swimming, Mesosauridae, Permian, Paraná Basin.

\begin{abstract}
Resumo Icnotaxonomia, morfologia funcional e contexto paleoambiental de pegadas de Mesosauridae do Permiano do Brasil. Pegadas subaquáticas de vertebrados são relativamente comuns no registro fossilífero, mas há poucos estudos sobre o tema devido à dificuldade na classificação e interpretação. No Brasil, pegadas subaquáticas foram registradas na Formação Irati (Permiano Inferior, Bacia do Paraná). De acordo com características morfológicas e interpretação morfofuncional, os icnofósseis foram designados como um novo táxon, Mesosaurichnium natans igen. nov. et isp. nov., e atribuídos aos répteis basais da família Mesosauridae. Com base na faciologia, os icnofósseis foram produzidos na área de transição entre as zonas de supramaré e intermaré e não corresponderiam à superfície original, pois essa encontrava-se coberta por uma fina camada de fragmentos de carapaças de crustáceos na ocasião da formação das pegadas. Os mesossaurídeos teriam produzido essas pegadas durante a natação próxima ao fundo, tendo a cauda como principal órgão propulsor. Eles seriam capazes de utilizar a cauda como o principal órgão de propulsão para natação rápida sob propulsão ondulatória, mas com o pé em forma de nadadeira atuando como um importante propulsor acessório durante a propulsão oscilatória, conferindo maior capacidade de manobra durante a natação lenta.
\end{abstract}

Palavras-chave: pegadas subaquáticas, natação, Mesosauridae, Permiano, Bacia do Paraná.

INTRODUCTION Vertebrate tracks produced under water are quite common in fossil record, despite the necessity of special conditions to their preservation. However, there are few studies on the theme due to difficulties in classification and interpretation of the tracks and its relationships with the trackmakers. In Brazil, subaqueous ichnofossils were previously recorded by Sedor $\&$ Silva (2004) at Irati Formation (Lower Permian, Passa Dois Group, Paraná Basin) and interpreted as drag marks of fingers produced by swimming reptiles identified as Mesosauridae Baur 1889 (Amniota, Sauropsida), which skeletal remains are abundant in this geological unit.

This was the first occurrence of ichnofossils related to these animals and provided the first direct evidence of swimming among the Mesosauridae. How- ever, there are doubts on the morphofunctional interpretation, ichnotaxonomy, preservation and paleoenvironmental context, being the aim of this work the discussion of these questions.

MATERIAL AND METHODS The studied material consists of 25 rock samples with ichnofossils from Irati Formation, collected between 1996 and 2003 by the authors F. A. Sedor and R. C. Silva. The samples are housed at the paleontological collection of Museu de Ciências Naturais, Setor de Ciências Biológicas, Universidade Federal do Paraná (MCN-SCB-UFPR), at Curitiba, Paraná State, Brazil.

The samples MCN.P.293a, MCN.P.293b, MCN.P.293c, MCN.P.760, MCN.P.761, MCN.P.762,

1 - CPRM - Companhia de Pesquisa de Recursos Minerais - Serviço Geológico do Brasil, Departamento de Geologia, Divisão de Paleontologia, Rio de Janeiro (RJ), Brazil. Email: rcsilva@rj.cprm.gov.br, paleoicno@yahoo.com.br

2 - Universidade Federal do Paraná, Setor de Ciências Biológicas, Museu de Ciências Naturais, Curitiba (PR), Brazil. Email: sedor@ufpr.br

3 - Universidade Federal do Rio de Janeiro, Museu Nacional, Departamento de Geologia e Paleontologia, Rio de Janeiro (RJ), Brazil.

Email: fernande@acd.ufrj.br 
MCN.P.763a, MCN.P.763b, MCN.P.764, MCN.P.765, MCN.P.766, MCN.P.767, MCN.P.774, MCN.P.851, MCN.P.852a,MCN.P.852b, MCN.P.852c, MCN.P.852d, MCN.P.853 and MCN.P.854 were collected at the Codapar limestone quarry, inside the limits of Municipality of Guapirama, Paraná State, Brazil (23 27'09.96” S / $50^{\circ} 02$ ' 10.92 " W, Fig. 1). The quarry, which was deactivated in 1998, is located few kilometers of the interstate highway PR 092 and can be accessed through a secondary road. The samples MCN.P.262 and MCN.P.266 were collected at the Metago (Metais de Goiás S/A) limestone quarry, Municipality of Portelândia, Goiás State, Brazil (17 $20^{\circ}$ ' 18.96" S / 52 $2^{\circ} 37^{\prime} 23.88^{\prime \prime}$ W, Fig. 1). The samples MCN.P.426, MCN.P.427 and MCN.P.428 were collected at the Sucal Mineração Ltda limestone quarry, Municipality of Perolândia, Goiás State, Brazil (17 29'00.0” S / 52 03' 11.60" W, Fig 1).

Silicon rubber casts were made from samples MCN.P.293a, MCN.P.293b and MCN.P.293c following techniques by Raup \& Stanley (1971), aiming a better description and illustration of the ichnofossils. Replicas of plaster of Paris and resin were also made. The samples were photographed with artificial light at low angles following techniques by Sarjeant (1975). Interpretative draws were made based in the original samples, photos, casts and replicas.

The footprints were measured using the following morphometric parameters: trace length (TL), trace width (TW) and distance between digits (DD). The footprints do not consist in impressions of the autopodia but drag marks of digits, so is not possible to use conventional parameters such as those described by Leonardi (1987) in measurement. Only the footprints with at least two traces and clear limits were considered for measuring because many footprints have gradual limits that cannot be precisely defined. The morphological concepts used in description of the ichnofossils were based in Leonardi (1987). Sixteen samples with thirty four footprints were measured. The mean, median, standard deviation and the coefficient of variation were calculated for each morphometric parameter.

GEOLOGICAL CONTEXT The Paraná Basin consists in an intracratonic basin of great extension with rocks deposited between Ordovician and Cretaceous (Schneider et al. 1974, Milani et al, 1994). It covers an area of ap-

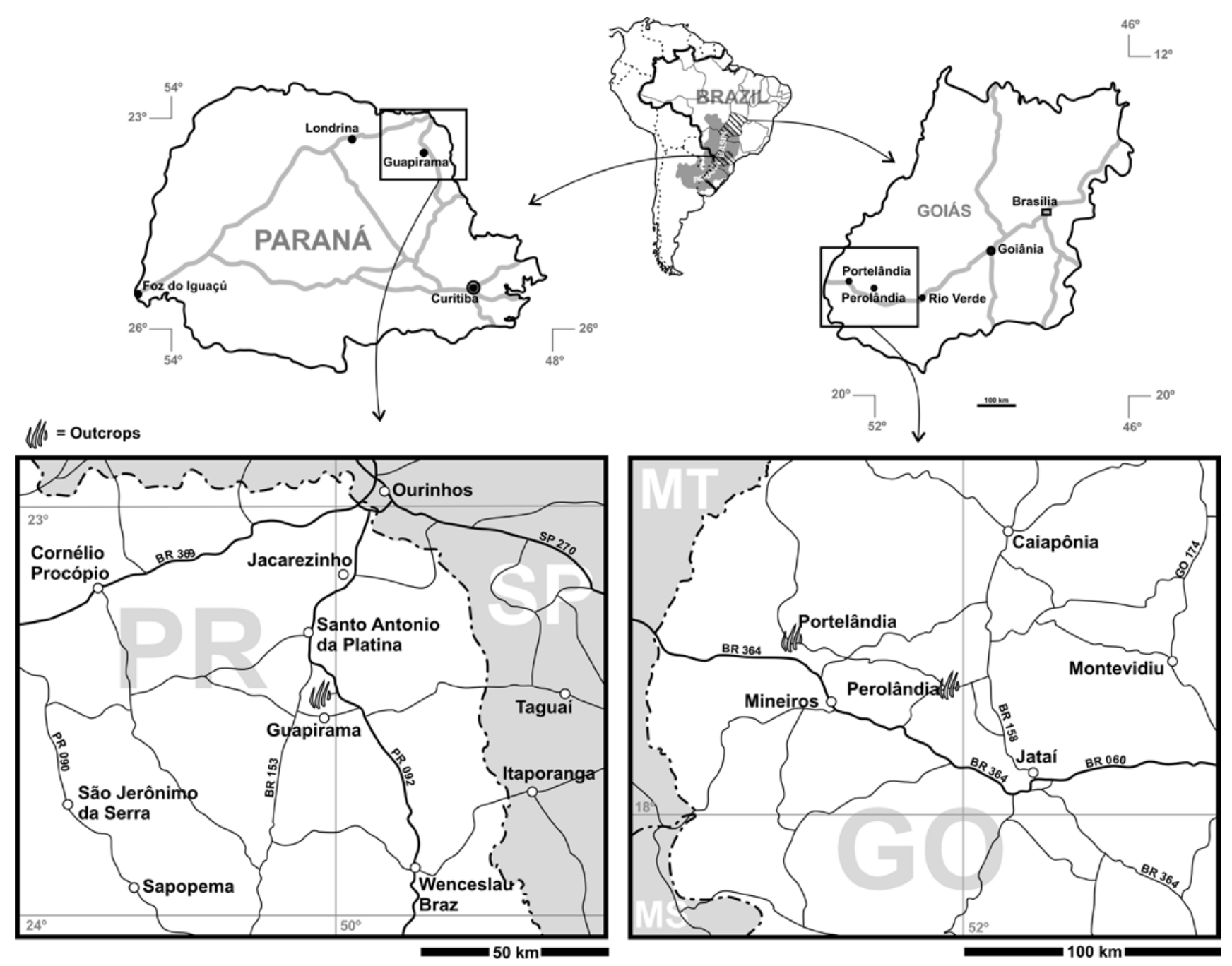

Figure 1 - Location of the studied outcrops at Paraná and Goiás States, Brazil. 
proximately $1.600 .000 \mathrm{~km}^{2}$ and occupies part of the territories of Brazil, Argentina, Uruguay and Paraguay. The Passa Dois Group consists in one of the Permian geological units and comprises the Irati, Serra Alta, Teresina, Corumbataí and Rio do Rasto Formations (Mendes 1967, Milani et al. 1994). The basal unit, Irati Formation, is characterized by dark shales and mudstones, pyrobitumous shales, sandstones and limestones. The main sedimentary structure is horizontal lamination, but ripple marks, cross lamination, oolites and intraformational conglomerate can occur in the carbonatic strata (Schneider et al. 1974). This formation was deposited in an extensive epicontinental sea, progressively more saline from base to top, in southern Gondwana. Fossils of mesosaurs, crustaceans, insects, sponges, fishes, bivalve mollusks and rare brachiopods are known in rocks from Irati Formation. The faciology shows a complex basin geometry during the deposition, with the occurrence of gulfs and bays of varied depths in a restricted sea (Milani et al. 1994).

A great chronostratigraphic problem of the Passa Dois Group rocks concerns the Kazanian age estimated for the Irati Formation by Brazilian researchers (e.g. Schneider et al. 1974, Cunha \& França 1994, Milani et al. 1994), based mainly in Daemon \& Quadros (1969). The Irati Formation is traditionally correlated to Whitehill Formation from Karoo Basin, in Southern Africa, based in lithology and fossil record. It is also correlated to Mangrullo Formation in Uruguay and to the lower portion of Chacabuco Formation, ChacoParaná Basin, Argentina (Lavina 1991). However, the Whitehill, Mangrullo and Chacabuco Formations were dated as Sakmarian-Artinskian (e.g. Oelofsen \& Araújo 1987, Lavina 1991), a younger age than the brazilian one. Recently, new palynological and radiometric studies attributed the Artinskian age for the Irati Formation (Premaor et al. 2006, Santos et al. 2006).

Description of the studied outcrops The Codapar quarry at Guapirama constitutes a vertical exposition of approximately 10 meters situated below the ground level (Fig. 2). The upper portion of the outcrop is heavily weathered while its lower portion is under water because of the deactivation of the mining activities, forming a small lake. Hence, the sedimentary log at

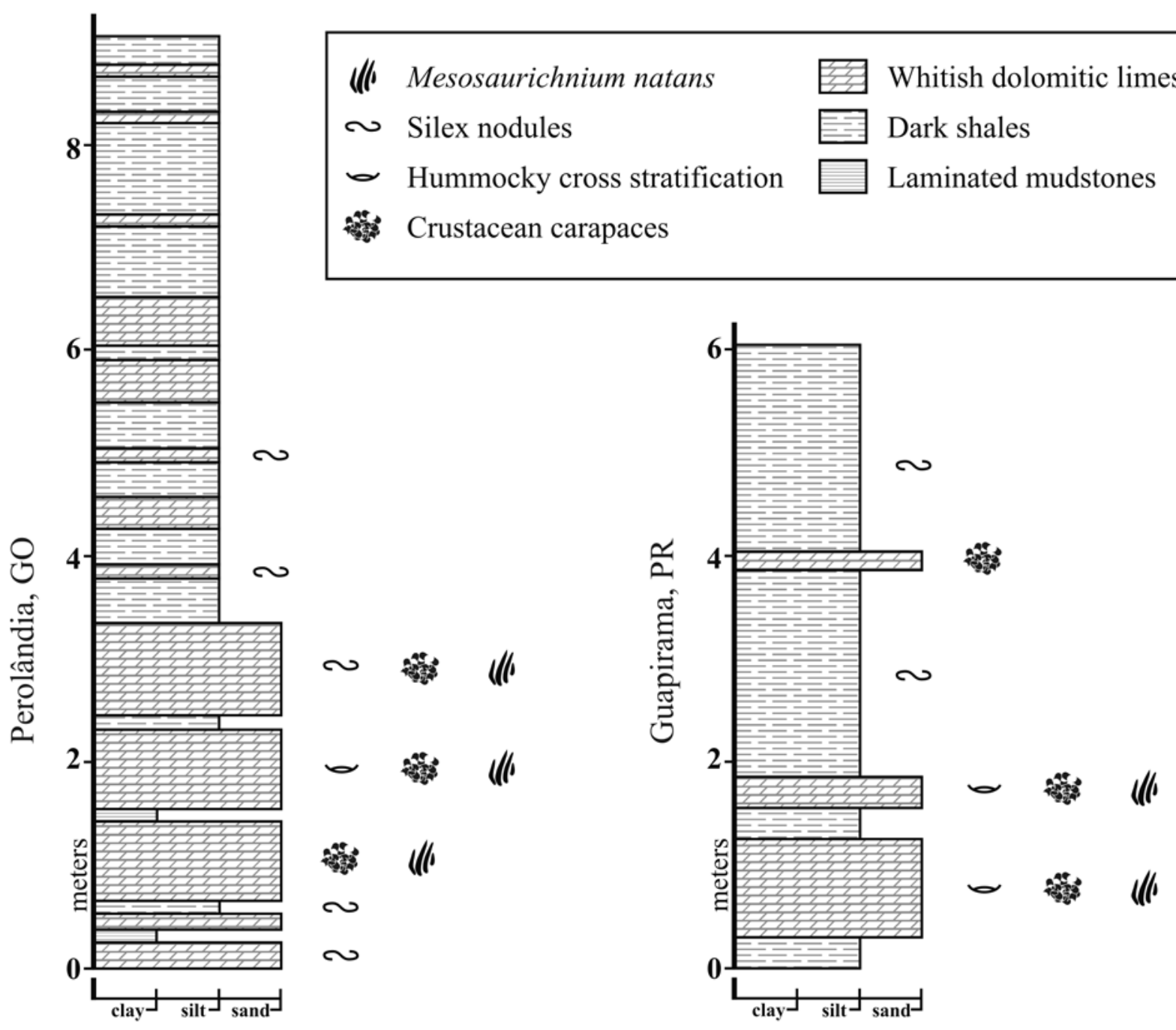

Figure 2 - Detailed section of Perolândia and Guapirama outcrops. 
figure 2 is tentative. The quarry is constituted by calcilutites, siltstones, dark pyrobitumous shales and dolomitic limestones with great accumulation of crustacean carapaces. Silex nodules and mesosaurids skeletal remains are abundant. The succession is dominated by rhythmic alternated layers of white to gray calcilutites and dark siltstones with horizontal lamination, which are vertically interrupted by carbonatic and dolomitic levels with sinuous and anastomosed ripple marks and hummocky cross stratification. The footprints occur in thin layers of calcilutite intercalated with dolomitic limestones with accumulation of crustacean carapaces. In these beds, is notable the orientation and size selection of the crustacean carapaces by flow action.

The Sucal Mineração Ltda limestone quarry at Perolândia was briefly studied and a detailed survey was not possible. However, a complete geological survey of this outcrop was provided by Anjos (2003). It consists in a vertical exposition of approximately 10 meters (Fig. 2 ). The lower portion shows whitish fine dolarenites with micritic texture intercalated by centimetric beds of gray siltic shales and mudstones. The ichnofossils occur in these dolarenite beds together with accumulations of crustacean carapaces, and many of them show orientation and size selection of the carapaces. The studied samples were found isolated from the outcrop and is not possible to know the exact stratigraphic position. The main sedimentary structures are horizontal lamination and hummocky cross stratification. The upper portion is formed by gray to dark siltic shales intercalated by centimetric beds of grayish micritic dololutites with horizontal lamination. Skeletal remains of mesosaurs occur all along the exposed section. The Metago quarry at Portelândia was not studied in the field.

\section{SYSTEMATIC ICHNOLOGY}

\section{Mesosaurichnium igen. nov.}

Diagnosis Footprints composed by two to four parallel or slightly divergent traces, which are regularly spaced and curved, with the internal side of the curve turned medially. The anterior extremity of each trace is acute while the posterior end of each trace is wider than the anterior one and medially curved with a rounded end. When four traces are present in a footprint, the two central ones are bigger and deeper than the others. The footprints can form regularly spaced trackways.

\section{Etymology Trace fossil of Mesosauridae.}

Remarks Some isolated and elongated traces could be confused with unilobated traces produced by invertebrates, but it can be refuted by the absence of a recognizable pattern of a track and the occurrence of the traces forming footprints. Besides, invertebrate ichnofossils are rare in Irati Formation, the only occurrence was identified in Goiás State, Brazil, as Didymaulichnus lyelli (Rouault, 1850) by Silva et al. (2003). Usually, ichnotaxonomic names are rarely used to designate subaque- ous tetrapod footprints due to great morphological variability and difficulties in identification of trackmaker and its anatomic features. Nevertheless, with a morphological analysis allied to a study of the variation, some patterns can be observed and used to diagnose, describe and name this kind of ichnofossil (e.g. Mcallister \& Kirby 1998, Mcallister 1989). The studied material clearly differs from others subaqueous ichnogenera, like Undichna Anderson 1976, composed by sets of horizontal and undulated traces, and Hatcherichnus Foster and Lockley 1997, which have bigger dimensions and an irregular pattern. Mesosaurichnium igen. nov. also differs from Lunichnium Walter 1983 by the absence of symmetric trackways and a median sinuous impression of the body or the drag of the tail (e.g. Minter \& Braddy 2006).

\section{Mesosaurichnium natans isp. nov.}

Material MCN.P.262, MCN.P.266, MCN.P.293a, MCN.P.293b, MCN.P.293c, MCN.P.426, MCN.P.427, MCN.P.428, MCN.P.760, MCN.P.761, MCN.P.762, MCN.P.763a, MCN.P.763b, MCN.P.764, MCN.P.765, MCN.P.766, MCN.P.767, MCN.P.774, MCN.P.851, MCN.P.852a,MCN.P.852b, MCN.P.852c,MCN.P.852d, MCN.P.853 and MCN.P.854.

Holotype - MCN.P.293b, footprints 1 and 2 (Fig. 3B).

Paratype - MCN.P.293a-5 (Fig. 3A); MCN.P.427-2

(Fig. 3C).; MCN.P.774-4 (Fig. 3D)

Diagnosis The same as for icnogenus.

Etymology Specific name natans, from Latin, to swim.

Description The footprint MCN.P.293b-1 is constituted by three parallel traces, each one with an acute anterior extremity and a wider, rounded and deeper posterior end; the medial trace is narrower and shorter than the others, which are slightly curved in the anterior portion. The footprint MCN.P.293b-2 have four semiparallel, slightly curved traces; the medial trace is smaller and the others have a discontinuity next to the posterior end. These two footprints correspond to a trackway fragment. Except for the holotype, the footprints are isolated and do not correspond to sequences that can be interpreted as trackways. In most samples there are chaotically arranged footprints, some of them with two to four divergent traces (MCN.P.262-1, MCN.P.293a-4, MCN.P.293a-7, MCN.P.293a-8, MCN.P.427-2, MCN.P.762-1, MCN.P.774-3); some of the footprints also occur superposed (e.g. MCN.P.293a-1 and MCN.P.293a-3; MCN.P.293a-4 and MCN.P.293a-5). Is also frequent in the samples the presence of isolated or double, very long parallel traces, that can be straight or sinuous (MCN.P.426-2, Fig. 4A; MCN.P.428-1, Fig. 4C; MCN.P.767, Fig. 4D; MCN.P.765, Fig. 5B; MCN.P.762, Fig. 5D; MCN.P.774-4), and long bifurcated sinuous traces (MCN.P.427; MCN.P.851, Fig. 5C), beyond $\mathrm{v}$ and $\mathrm{z}$-shaped traces (MCN.P.428-2, Fig. 4C; MCN.P.761-3, Fig. 5A; MCN.P.764-1, Fig. 4B). The table 1 shows the dimensions of the studied specimens. 

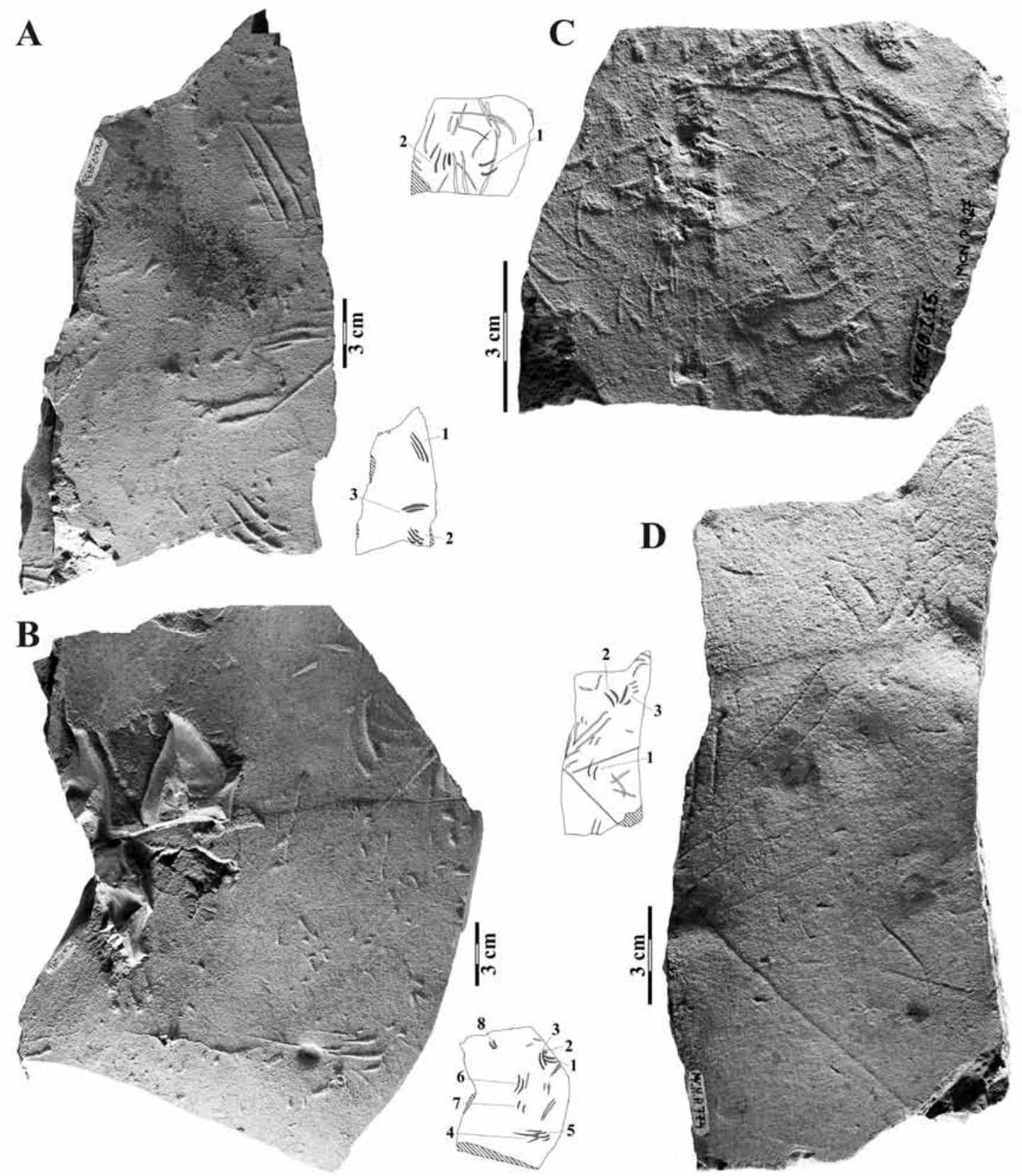

Figure 3 - Mesosaurichnium natans igen. nov. et isp. nov., from the Irati Formation: A) Sample MCN.P.293a; B) Sample MCN.P.293b; C) Sample MCN.P.427; D) Sample MCN.P.774.

DISCUSSION Among the several faciologic interpretations of the Irati Formation, those conduced by Lavina (1991), Hachiro \& Coimbra (1991) and Santos Neto (1993) are the most complete and detailed ones, and several enhancements were made since the work by Figueiredo Filho (1972). A tentative comparison of these facies is presented at table 2 . The facies where the ichnofossils were found in the quarry at Guapirama can be compared to the Lithofacies BB of Santos Neto (1993), described for rocks of São Paulo State, Brazil, which corresponds to carbonate banks deposited in the transition zone between supratidal and subtidal zones. The others faciologic interpretations are similar. However, the faciology of the studied outcrop, which is composed of rhythmic layers of siltstone and calcilutite interrupted by tempestite deposits, suggest that it can correspond to a lower shoreface succession formed below fair weather wave base but affected by storm wave base (e.g. Walker \& Plint 1992).

The beds with accumulation of crustacean carapaces would be originated with the erosion of bottom sediments by storm waves, transporting and redepositing the suspended material, including sediment and bioclasts, according to size and density of the clasts. The size selection and orientation of the carapace fragments support the hypothesis of hydrodynamic transport and selection. The footprints are found in the base of these beds, which occur in association with hummocky cross stratification in the Codapar quarry at Guapirama, cor- 

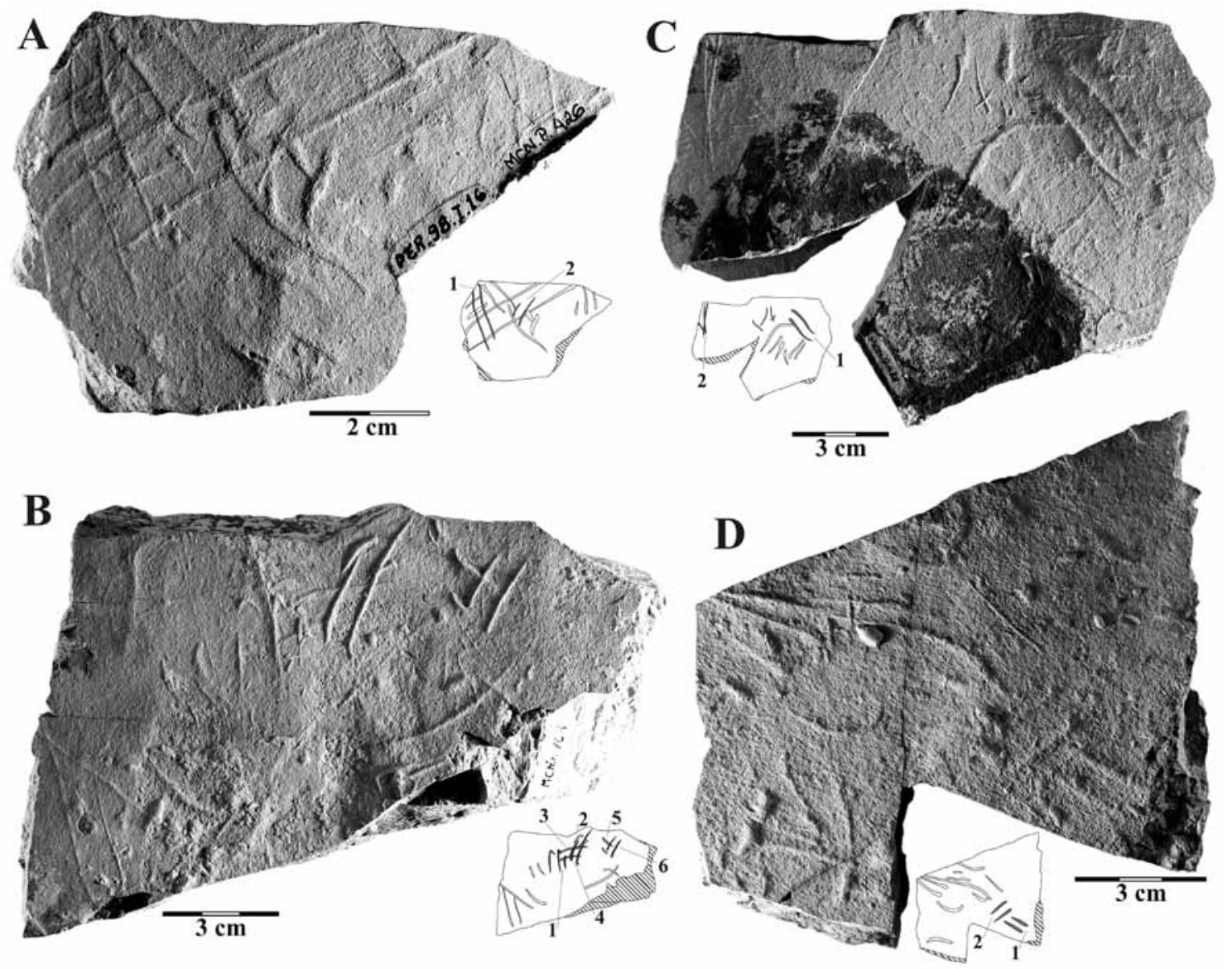

Figure 4 - Mesosaurichnium natans igen. nov. et isp. nov., from the Irati Formation: A) Sample MCN.P.426; B) Sample MCN.P.764; C) Sample MCN.P.428; D) Sample MCN.P.767.
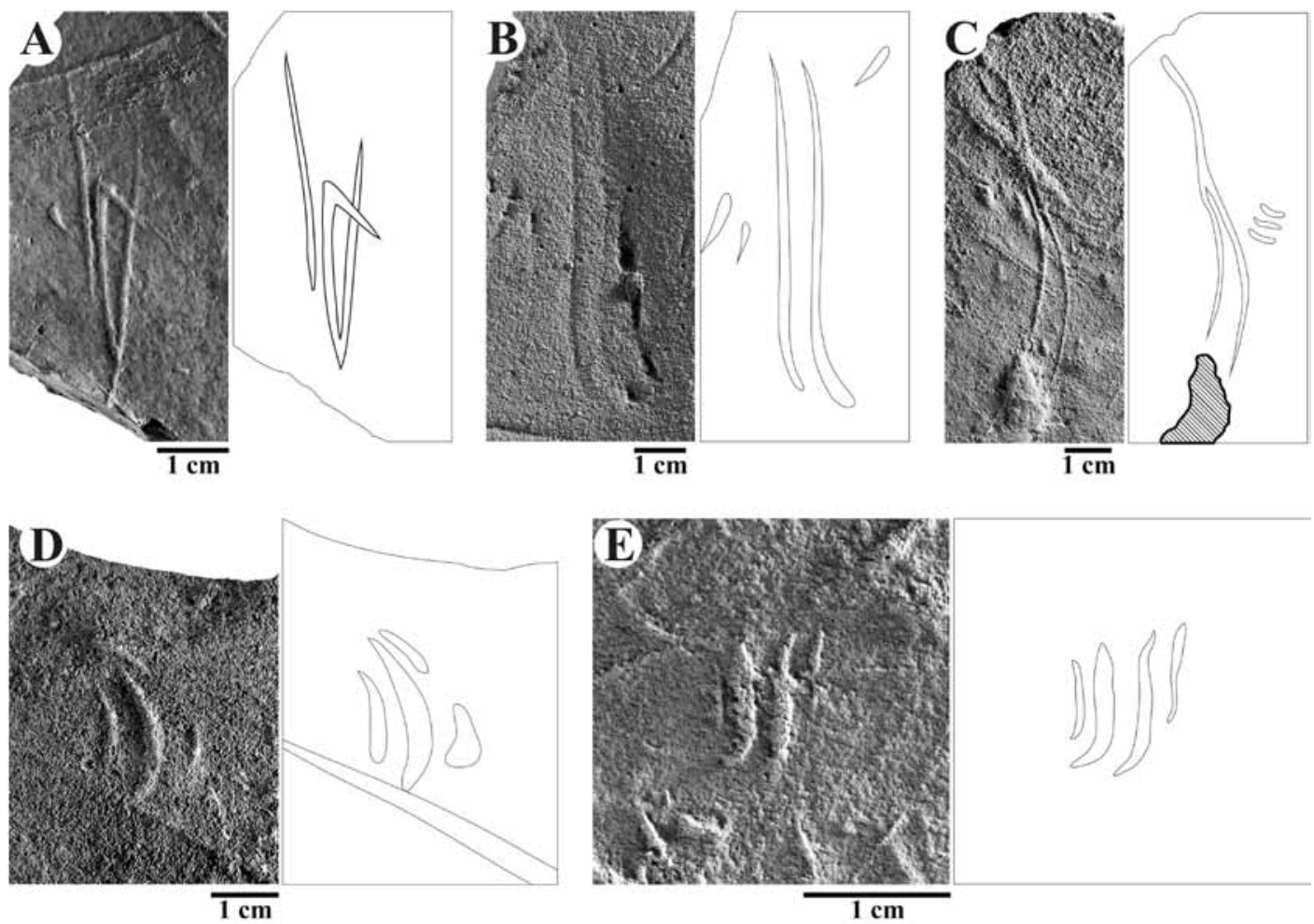

Figure 5 - Mesosaurichnium natans igen. nov. et isp. nov., from the Irati Formation: A) Sample MCN.P.761-3; B) Sample MCN.P.765; C) Sample MCN.P.851; D) Sample MCN.P.762; E) Not numbered sample, Perolândia outcrop. 
Table 1 - Mesosaurichnium natans igen. nov. et isp. nov. Statistic data of morphometric parameters: TL = trace length; $T W=$ trace width; $D D=$ distance between digits.

\begin{tabular}{c|c|c|c|c|c|c|c|c|c|c|c|c|c}
\hline & \multicolumn{4}{|c|}{ TL $(\mathrm{cm})$} & \multicolumn{3}{|c|}{ TW $(\mathrm{cm})$} & \multicolumn{3}{|c}{ DD $(\mathrm{cm})$} \\
\hline & I & II & III & IV & I & II & III & IV & & I-II & II-III & III-IV \\
\hline Mean & 1.78 & 2.52 & 2.50 & 1.48 & 0.13 & 0.20 & 0.20 & 0.17 & 0.46 & 0.63 & 0.55 \\
\hline Median & 1.33 & 2.33 & 2.44 & 1.19 & 0.12 & 0.20 & 0.21 & 0.18 & 0.43 & 0.56 & 0.46 \\
\hline Standard deviation & 1.28 & 0.96 & 0.96 & 0.68 & 0.04 & 0.08 & 0.07 & 0.06 & 0.14 & 0.20 & 0.23 \\
\hline C. of variability (\%) & 71.91 & 38.09 & 38.40 & 45.94 & 30.76 & 40.00 & 35.00 & 35.29 & 30.43 & 31.75 & 41.81 \\
\hline
\end{tabular}

Table 2 - Comparison between the lithofacies proposed for the Irati Formation.

\begin{tabular}{|c|c|c|c|}
\hline Figueiredo Filho 1972 & Lavina 1991 & Hachiro and Coimbra 1991 & Santos Neto 1993 \\
\hline \multirow{2}{*}{ Facies Valente } & \multirow{2}{*}{ No-bituminous pelites } & Faciological association II & \\
\hline & & Faciological association IV & \\
\hline \multirow{5}{*}{ Facies Tiaraju } & Bituminous shales & Faciological association III & \\
\hline & Carbonatic tempestites & & \\
\hline & & Faciological association $\mathrm{V}$ & Lithofacies BB \\
\hline & \multirow[t]{2}{*}{ Carbonatic turbidites } & \multirow{2}{*}{$\begin{array}{l}\begin{array}{l}\text { Faciological } \\
\text { association } \\
\text { VI }\end{array} \\
\begin{array}{r}\text { Faciological } \\
\text { association VII }\end{array}\end{array}$} & Lithofacies LE \\
\hline & & & Lithofacies LF \\
\hline
\end{tabular}

responding to the base of a tempestite.

Based in the interpretation of the depositional system and ichnofossils, Mesosaurichnium natans igen. nov. et isp. nov. can be attributed to a aquatic swimming tetrapod which lived in the environment represented today by the Irati Formation. In a preliminary work by Sedor \& Silva (2004), these footprints were attributed to Mesosauridae, the only tetrapods known in Irati Formation. The Mesosauridae family are composed by three species, Mesosaurus tenuidens Gervais 1864, Stereosternum tumidum Cope 1886 and Brazilosaurus sanpauloensis Shikama and Ozaki 1966. Morphology and dimensions of the locomotory appendages of these animals are also compatible with the footprints. However, as the posterior locomotory appendage is anatomically similar in the three species (e.g. Araújo 1976), it's not possible to attribute the footprints to a particular species of Mesosauridae.

The mesosaurids have adaptations to aquatic habits usually cited in literature (e.g. Cope 1886, McGregor 1908, Williston 1914, Romer 1956, Rösler \& Tatizana 1983), as a long and slender body, long and laterally compressed tail, skull with a long rostrum and nostrils just if front of the orbits, pachyostotic ribs, and autopodia with interdigital web. Their posterior locomotory appendages are longer and stronger than the anterior ones.
In basal reptiles, the proximal and distal expansions of the humerus lie in different planes, being frequently at nearly right angle (Romer 1956). This twist allowed the anterolateral position of the forearm and manus in terrestrial reptiles. However, the mesosaurids had a minor twist on the humerus $\left(\sim 55^{\circ}\right.$, Sedor 2004), which probably restricted the anterolateral movements of the hands. The epipodial elements of the pectoral limb, radius and ulna, are incompletely ossified at their ends. There is no ossified olecranon, and here, as in many other aquatic types, it may have been absent in life, with motion of the epipodials on the humerus reduced to a simple flexion (Romer 1956). The manus in mesosaurids shows little apparent modification from the primitive pattern, with short digits and without hyperphalangism (Romer 1956, Sedor \& Ferigolo 1999). The considerable size of the hind limb relative to the body of mesosaurids suggests that they had a propulsive action, whereas the pectoral limbs are of modest size and little specialized, and may have been passive in aquatic locomotion (Romer 1956). The general pelvic structure is similar to basal forms and, as befits the aquatic nature of this animal, ossification of the girdle is reduced. The femur is of an essentially terrestrial type, cylindrical with slightly expanded ends, slightly concave dorsally in the proximal half and dorsally convex 
in distal half (Romer 1956, Sedor 2004). The articular head is an elongade oval, like in basal reptiles, and the bone could apparently rotate rather freely in the acetabulum, in contrast to the restricted motion of the humerus (Romer 1956). The second segment of the limb, the tibia and fibula, is well developed, short in relation to the others and, except for some flattening, appear to be of normal build, similar to the basal terrestrial forms (Romer 1956). The fibula shows a more significant biomechanic function, being aligned with the calcaneum and the astragalus (Sedor \& Ferigolo 1999). According to McGregor (1908), the knee was strongly flexed as in salamanders during swimming. The pes is large relative to the body and resembles the basal pattern in many aspects. Digit I is the smallest and the size of the digits increases from I to V. Probably there was no great degree of movement at any one joint within the tarsus or at its proximal or distal articulation, the "paddle" operating as a unit (Romer 1956, Sedor \& Ferigolo 1999). Not only in mesosaurids but also in various other waterdwelling types, the pes tends to lose its angulation on the crus and the rotary motion associated with it and to become a flattened, hinged paddle, extending directly distally from the crus in the same plane (Romer 1956).

The build of the hind limbs resembles that of the marine crocodilians, except for the greatly expanded pes. The alignment of the femur with the epipodial bones and pes suggests the movements of adduction/ abduction and restriction of other movements (Sedor \& Ferigolo 1999). The reduction in mobility between the carpal and tarsal elements and their neighbors, common in aquatic tetrapods (Romer 1956), results from dorsoventral flattening of these elements and their alignment with the epipodial elements, which probably made it impossible for the mesosaurids to displace both manus as pes in anterolateral position.

Tetrapods which leave subaqueous traces locomote with either discontinuous oscillatory propulsion or continuous undulatory propulsion of the body and tail (McAllister 1989). In animals that use the undulatory propulsion, such as sea snakes and most of the fish, body and tail move symmetrically from side to side, producing a diagonal lateroposterior stroke in relation to the direction of movement (McAllister 1989, Hildebrand 1995). This type of propulsion provides greater speed to the animal at the expense of maneuverability. In oscillatory swimming the paired limbs are used as propellants, with a power stroke that propels the body followed by a recovery stroke and thus acting as paddles. During the power stroke, the largest side of the fin is oriented orthogonally to the direction of movement as the limb rotates around the base, describing an arc (Hildebrand 1995). Tetrapods equipped with interdigital membrane could flex their autopodia and curl their digits during the recovery stroke in order to reduce drag, and the same should occur with the mesosaurids. Oscillatory swimmers include frogs, turtles, birds that swim on the surface and several mammals. These animals are mostly slow swimmers, but with good maneuverability (Hildebrand 1995). In crocodilians, salamanders and aquatic lizards, the limbs are placed aligned to the body during undulatory swimming to reduce drag while the oscillatory swimming is used during slow movement, where maneuverability is more important. The alligator swims sinuously with its front legs collapsed and extended by the side of the body; its hind legs are used more as propellers, with the knee flexed and the feet turned outward and expanded. The legs of proganosaurs doubtless were used in the same way (Willinston 1914). According to morphological characteristics, the mesosaurids probably were capable of both types of swimming, oscillatory and undulatory. The strong and laterally flattened tail and the pes converted into a large and wide fin, strong enough to resist water pressure with flattened and reinforced metapodiais and phalanges, seem to support this hypothesis. Since the mesosaurids are derived from basal terrestrial reptiles with sprawling posture and because of the limitation in anterior displacement of autopodia, the movement of abduction used in swimming should start on the lateral position in relation to the body, with the sole facing posteriorly, and end with the pes in mesial position in relation to the body (Fig. 6).

According to these data, is possible to affirm that the mesosaurids used the tail as the main propelling organ for fast swimming (undulatory propulsion) but with the paddle-like pedes acting as important accessory propellant, conferring greater maneuverability during slow swimming (oscillatory propulsion). The hands are unlikely to be able to produce prints and at least the vast majority of the tracks can be attributed to the movement of the pedes. The means of the trace lengths, equivalent to the arc described by the posterior locomotory appendage during the abduction, and of the distance between digits (Tab. 1) are compatible with the dimensions of the pedes of mesosaurids (e.g. McGregor 1908, Williston 1914, Romer 1956, Araújo 1976). Thus, the shape of the pes and its alignment with the body axis (Williston 1914, Sedor \& Ferigolo 1999) could allow preferentially the central digits (II, III and IV) to touch the bottom (Fig. 7). The digit I, being the shorter, only rarely touch the substrate, forming a possible small drag mark as shown in the footprints MCN.P.293a-2 and MCN.P.427-2 (Fig. 3). Due to a more lateral position of the pedes at the beginning of the adduction, the digit V would occupy a position closer to the horizontal and also rarely could touch the substrate, as evidenced in the footprint MCN.P.427-2. If the typical footprints of three traces were produced by the digits I, II and III or III, IV and V, would never be preserved impressions of the digits I and $\mathrm{V}$ respectively.

The statistic study of the footprints reveals that the mean and median have similar values, constituting good representatives of the studied population (Leonardi 1987). The trace length (TL) have a higher coefficient of variation than the trace width (TW) and the distance between digits, which indicates that the last two are better to diagnose these footprints.

Most of the studied samples provide footprints preserved as convex hyporrelief, reflecting a bias in collecting probably because this kind of preservation 


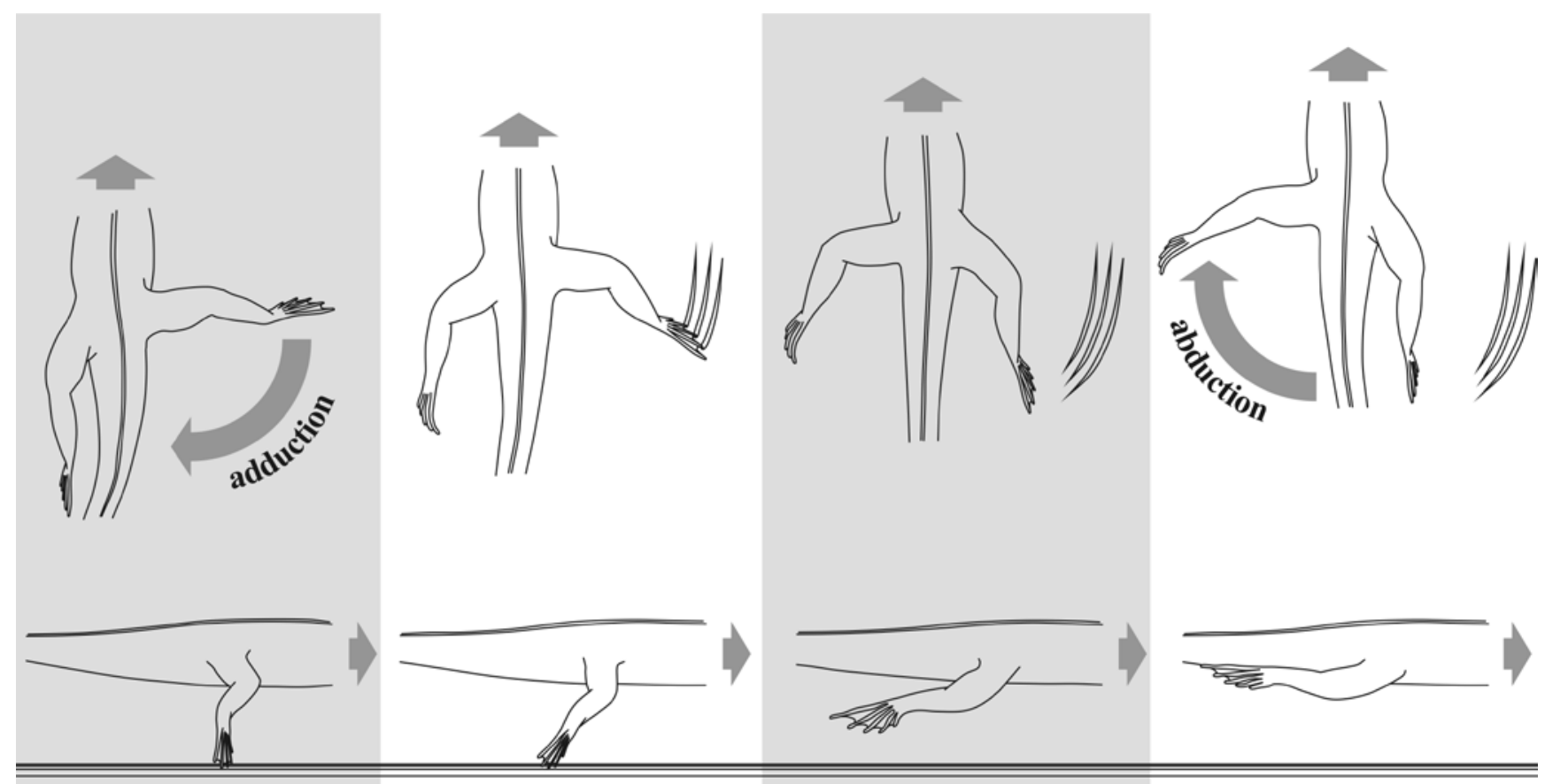

Figure 6 - Probable stages of the movements of adduction and abduction of the hind limb of a Mesosauridae during the oscillatory slow swimming, based on the morphology of the ichnofossils and osteological characters.

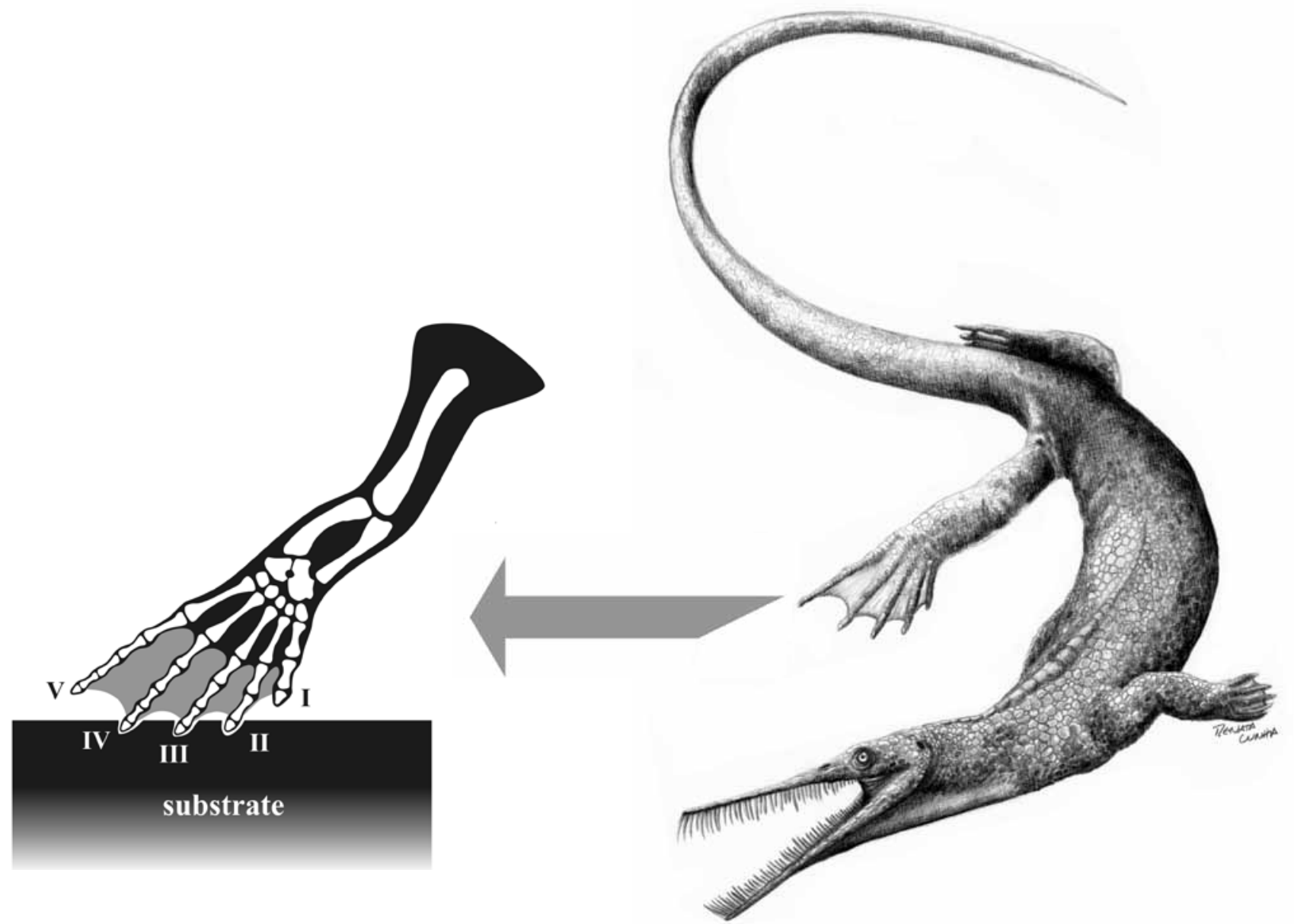

Figure 7 - Reconstruction of a Mesosauridae showing the position of the pes at the beginning of adduction movement of the hind limb and the angle of its axis relative to the substratum, as suggested by the study of osteological characters and ichnofossils (artwork by Renata Cunha). 
is more easily viewed in the field. Besides, scratches produced by the work of the machines at the quarry can be confused with traces in concave epirrelief.

McAllister \& Kirby (1998) and McAllister (1989) established characters to recognize subaqueous footprints, many of them found in the studied samples: reflecture of digits, depth of the mark corresponding to the arc of digit, elongation of traces, posterior overhang, impression of distal digits, trace lengths excessively variable compared to widths and unexpected configurations. The occurrence of these characters together with the paleoenvironmental interpretation for these rocks confirms the hypothesis of an underwater origin as suggested by Sedor \& Silva (2004). According to these authors, the footprints would be produced by the locomotion of the trackmaker through seminatation in shallow water, with the fingers touching the bottom while the body and tail floats. Footprints with a similar origin were described by Avanzini et al. (2005) and Silva et al. (2008), the latter describing an animal with the pes turned lateroposteriorly, which could be able to swim in a similar manner to mesosaurids. However, the collected data contradict the interpretation by Sedor \& Silva (2004). The beds with ichnofossils were deposited under few meters deep (Lavina 1991, Santos Neto 1993) and its production only could be possible during swimming with the complete submersion of the trackmaker.

Another factor that supports the hypothesis of a deeper water column during the production of the ichnofossils is the absence of traction footprints, since there are only footprints produced by swimming. The occurrence of traction footprints together with drag marks of autopodia is typical of seminatation tracks (e.g. Silva et al. 2007, 2008), due to variations in the size of the trackmakers relative to the depth of the water sheet. In shallow waters, small sized or young animals would produce drag marks of fingers in the substrate while bigger animals would walk on the bottom producing partial or complete impressions of autopodia. If the depth is slightly higher, the biggest animals would produce drag marks of fingers and the smallest ones wouldn't leave any trace (e.g. Foster \& Lockley 1997). This fact was noted in the study of subaqueous footprints of Moenkopi Formation, Utah, USA, by McAllister \& Kirby (1998). In the Irati Formation there are drag marks of fingers produced by animals of different sizes (Fig. 5E), and any autopodia impression was found, which can also support the hypothesis of a deeper water column during the production of the ichnofossils.

The study of preservation of Mesosaurichnium natans igen. nov. et isp. nov. provides important data about how it was produced. Usually, subaqueous footprints have kick-off scours caused by the action of swirls, created by the fast passage of the autopodia near to the substrate, which suspend and redeposit the sediment just behind the footprint (McAllister \& Kirby 1998, Swanson \& Carlson 2002). These marks indicate that the surface with footprints had been exposed at the time of passage of the trackmaker. This kind of feature is not present in any of the studied ichnofossils, which can indicate that they were not directly produced in an exposed surface. This fact can be explained as follows: during the storm events, the crustacean carapaces were redeposited together with reworked fine grained carbonatic sediments, which form milimetric lenses between the beds with carapaces; when the animals touched the bottom, its fingers crossed the layer with carapaces and reached the thin layers of sediment below, protected from the wave action. Probably, the depth which the fingers could enter in the substrate was limited by the interdigital membrane (Rösler \& Tatizana 1983), what could explain the nearly constant depth of the traces. However, the footprints would not correspond to classic undertracks since there was no pressure of the autopodia on the substrate in order to deform the lower layers, but penetration of the finger ends in the sediment.

Yet following McAllister \& Kirby (1998), the wider portion of subaqueous footprints corresponds to the posterior extremity, contrasting with the interpretation by Sedor \& Silva (2004), according to which the anterior end is wider than the posterior. Another element that can support the interpretation by McAllister and Kirby (1998) is the presence of traces (e.g. MCN.P.266-2, MCN.P.853-1, MCN.P.427-1, MCN.P.764-1, MCN.P.764-4, MCN.P.774-2, MCN.P.293a-4, MCN.P.293a-5, MCN.P.293b-3, Figs. 3 and 4) with a highly curved, comma-shaped extremity. This feature can be interpreted as reflecture of digits, produced during the final stage of propelling by the feet (Thulborn \& Wade 1989). Thus, this extremity would correspond to the posterior end of the trace.

The horizontal distribution of the footprints of Irati Formation is rather chaotic, which is typical of subaqueous footprints (Peabody 1956) because the animal did not use the substrate to propel the body, but touched it accidentally. Likewise, there are no significant sequences of footprints that characterize tracks, which can be evidence that the long and laterally compressed tail of the mesosaurids was probably the main propellant organ during swimming, and the feet were used only as auxiliary propellants and in changes of direction. However, most of the ichnofossils is represented by double or triple curved traces which can be interpreted as drag marks of digits produced during the arc of motion of the locomotory appendage. This kind of movement is typical of animals that use the autopodia as propellants for swimming (e.g. Peabody 1956, Peabody 1959, McAllister \& Kirby 1998, Diedrich 2002, Minter \& Braddy 2006). Some variations of these traces can be observed also. Footprints with divergent traces (MCN.P.427-2, MCN.P.853-1, MCN.P.774-3, MCN.P.262-1) can be attributed to the increase of the interdigital angles during the propelling stage, inflating the natatory membranes and increasing the surface area of autopodia. The long isolated or double, straight to sinuous traces which occur in several samples (MCN.P.765, MCN.P.762, MCN.P.774, MCN.P.426, MCN.P.427) can be interpreted as drag marks of fingers produced on the substrate when the movements of propulsion ceased but the animal continued to move by 
inertia, generating straight traces, or when the propulsion was offered solely by the meandering movement of the tail, producing sinuous traces. The bifurcated traces observed in some samples (MCN.P.427, MCN.P.761, MCN.P.851, MCN.P.852b) are more difficult to be interpreted, but they can represent variations of z-traces as described by McAllister \& Kirby (1998), interpreted as traces produced by a briefly interruption in the propulsion movement of the autopodia.

CONCLUSIONS The ichnofossils of Irati Formation was designated as Mesosaurichnium natans igen. nov. et isp. nov. and attributed to Mesosauridae (Sauropsida, Proganosauria). They were produced in a lower shoreface affected by storm waves and do not correspond to the original sedimentary surface, which was covered by a thin layer of crustacean shelly fragments during the production of the tracks. The tracks were produced by mesosaurids during the swimming next to the bottom with the long tail maintaining the propulsion. The mesosaurids were able to use the tail as the main propelling organ for fast swimming under undulatory propulsion, but with the paddle-like pedes acting as important accessory propellant during oscillatory propulsion, conferring greater maneuverability during slow swimming.

Acknowledgements Thanks go to: Ismar de Souza Carvalho and Leonardo Borghi de Almeida (Universidade Federal do Rio de Janeiro), Cibele Schwanke (Universidade do Estado do Rio de Janeiro), Ronaldo Fernandes (Museu Nacional, Universidade Federal do Rio de Janeiro), and Giuseppe Leonardi for critical comments; Codapar (Companhia de Desenvolvimento Agropecuário do Paraná), Metago (Metais de Goiás S/A) and Sucal Mineração Ltda for the access to the studied areas. Financial support was provided by $\mathrm{CNPq}$ (Conselho Nacional de Desenvolvimento Científico e Tecnológico), FAPERJ (Fundação Carlos Chagas Filho de Amparo à Pesquisa no Estado do Rio de Janeiro) and CAPES (Coordenação de Aperfeiçoamento de Pessoal de Nível Superior).

\section{References}

Anjos C.W.D. 2003. A influência térmica de intrusões ígneas sobre pelitos e rochas carbonáticas da Formação Irati, em Goiás. MsC. Thesis, Programa de Pós-Graduação em Geologia, Instituto de Geociências, Universidade de Brasília, 118 p.

Araújo D.C. 1976. Taxonomia e Relações dos Proganosauria da Bacia do Paraná. Anais da Academia Brasileira de Ciências, 48:91-16.

Avanzini M., García-Ramos J.C., Lires J., Menegon M., Piñuela L., Fernández L.A. 2005. Turtle tracks from the Late Jurassic of Asturias, Spain. Acta Palaeontologica Polonica, 50:743-755.

Cope E.D. 1886. A contribution to the vertebrate paleontology of Brazil. Proceedings of the American Philosophical Society, 23:7-15.

Cunha P.R.C. \& França A.B. 1994. Estudo das taxas de sedimentação das formações Teresina e Rio do Rasto Bacia do Paraná. Boletim de Geociências da Petrobrás, 8:347-359.

Daemon R.F. \& Quadros L.P. 1969. Bioestratigrafia do Neopaleozóico da Bacia do Paraná. In: SBG, Congresso Brasileiro de Geologia, 24, Anais, p. 355-412.

Diedrich C. 2002. Vertebrate track bed stratigraphy at new megatrack sites in the Upper Wellenkalk Member and orbicularis Member (Muschelkalk, Middle Triassic) in carbonate tidal flat environments of the western Germanic Basin. Palaeogeography, Palaeoclimatology, Palaeoecology, 183:185-208.

Figueiredo Filho P.M. 1972. A faciologia do Grupo Passa Dois no Rio Grande do Sul. Revista Brasileira de Geociências, 2:216-235.

Foster J.R. \& Lockley M.G. 1997. Probable crocodilian tracks and traces from the Morrison Formation (Upper Jurassic) of eastern Utah. Ichnos, 5:121-129.

Hildebrand M. 1995. Análise da estrutura dos vertebrados.
São Paulo, Atheneu, 700 p.

Hachiro J. \& Coimbra A.M. 1991. Sistemas deposicionais da Formação Irati no Estado de São Paulo. In: SBG, Simpósio de Geologia do Sudeste, 2, Atas, p. 405-413.

Lavina E.L. 1991. Geologia sedimentar e paleogeografia do Neopermiano e Eotriássico (Intervalo Kazaniano - Scythiano) da Bacia do Paraná. PhD Thesis, PósGraduação em Geociências, Universidade Federal do Rio Grande do Sul, 333 p.

Leonardi G. (ed.) 1987. Glossary and manual of Tetrapod footprint Palaeoichnology. Brasília, DNPM, 117 p.

McAllister J.A. 1989. Dakota Formation tracks from Kansas: implications for the recognition of tetrapod subaqueous traces. In: Gillete D.D. \& Lockley M.G. (eds.) Dinosaur tracks and traces. Cambridge University Press, p. 343348.

McAllister J.A. \& Kirby J. 1998. An occurrence of reptile subaqueous traces in the Moenkopi Formation (Triassic) of Capitol Reef National Park, South Central Utah, USA. National Park Service, Technical Report, 98(1):45-49.

McGregor J.H. 1908. Mesosaurus brasiliensis nov. sp. In: Relatório Final Comissão de Estudos Minas de Carvão de Pedra do Brasil, Rio de Janeiro, 2:301-336.

Esta referencia permite o acesso irrestrito a todos os pesquisadores/leitores da RBG? Em caso negativo, solicitamos gentilmente a sua substituição por um trabalho publicado ou a sua retirada. No caso da retirada da referencia, a citação poderá permanecer como McGregor inédito, para garantir direitos autorais.

Mendes J.C. 1967. The Passa Dois Group (the Brazilian portion of the Paraná Basin). In: Bigarella J.J., Becker R.D., Pinto I.D. (eds.) Problems in Brazilian Gondwana Geology. International Symposium on the Gondwana Stratigraphy and Palaeontology, 1, Universidade Federal do Paraná, Curitiba, p. 119-166. 
Milani E.J., França A.B., Schneider R.L. 1994. Bacia do Paraná. Boletim de Geociências da Petrobrás, 8:69-82.

Minter N.J. \& Braddy S.J. 2006. The fish and amphibian swimming traces Undichna and Lunichnium, with examples from the Lower Permian of New Mexico, USA. Palaeontology, 49:1123-1142.

Oelofsen B. \& Araújo D.C. 1987. Mesosaurus tenuidens and Stereosternum tumidum from the Permian Gondwana of both Southern Africa and South America. South African Journal of Science, 83:370-372.

Peabody F.E. 1956. Ichnites from the Triassic Moenkopi Formation of Arizona and Utah. Journal of Paleontology, 30:295-468.

Peabody F.E. 1959. Trackways of living and fossil Salamanders. University of California Publications in Zoology, 63:1-72.

Premaor E., Fischer T.V., Souza P.A. 2006. Palinologia da Formação Irati (Permiano Inferior da Bacia do Paraná), em Montividiu, Goiás, Brasil. Revista del Museo Argentino de Ciencias Naturales - Nova Serie, 8:221230.

Raup D.M. \& Stanley S.M. 1971. Principles of Paleontology. San Francisco, W.H. Freeman and Company, 388 p.

Romer A.S. 1956. Osteology of the Reptiles. Chicago University Press, 772 p.

Rösler O. \& Tatizana C. 1983. As membranas natatórias em Stereosternum tumidum. Coletânea de trabalhos paleontológicos, DNPM, Série Geológica, 27, Série Paleontologia e Estratigrafia, 2, 1985, p. 129-131.

Santos R.V., Souza P.A., Alvarenga C.J.S., Dantas E.L., Pimentel M.M., Oliveira C.G., Araújo L.M. 2006. Shrimp U-Pb zircon dating and palynology of bentonitic layers from the Permian Irati Formation, Paraná Basin, Brazil. Gondwana Research, 9:456-463.

Santos Neto E.V. 1993. Caracterização geoquímica e paleoambiente deposicional da seqüencia carbonatopelítica superior do Membro Assistência, Formação Irati no Estado de São Paulo, Bacia do Paraná. MsC Thesis, Pós-Graduação em Geologia da Universidade Federal do Rio de Janeiro, 203 p.

Sarjeant W.A.S. 1975. Fossil tracks and impressions of vertebrates. In: Frey R.W. (ed.) The Study of Trace Fossils. New York, Springer-Verlag, p. 283-324.

Schneider R.L., Mühlmann H., Tommasi E., Medeiros R.A., Daemon R.F., Nogueira A.A. 1974. Revisão Estratigráfica da Bacia do Paraná. In: SBG, Congresso Brasileiro de Geologia, 28, Anais, 1:41-66.

Sedor F.A. 2004. Osteologia do úmero e apêndice locomotor pélvico de Brazilosaurus sanpauloensis Shikama \& Ozaki, 1966 (Mesosauridae), da Formação Irati, Permiano Superior da Bacia do Paraná, Brasil. In: SBH, Congresso Brasileiro de Herpetologia, 1, Resumos, CDRom.

Sedor F.A. \& Ferigolo J. 1999. Apêndices locomotores escapulares e pélvicos em Brazilosaurus sanpauloensis Shikama \& Ozaki, 1966 (Proganosauria, Mesosauridae), Formação Irati, Permiano da Bacia do Paraná, Brasil. In: SBP, Congresso Brasileiro de Paleontologia, 16, Boletim de Resumos, p. 104.

Sedor F.A. \& Silva R.C. 2004. Primeiro registro de pegadas de Mesosauridae (Amniota, Sauropsida) na Formação Irati (Permiano Superior da Bacia do Paraná) do Estado de Goiás, Brasil. Revista Brasileira de Paleontologia, 7:269-274.

Silva R.C., Fernandes A.C.S., Sedor F.A. 2003. Ocorrência de icnofósseis de invertebrados na Formação Irati (Permiano Superior da Bacia do Paraná, Brasil). Arquivos do Museu Nacional, 61:261-266.

Silva R.C., Carvalho I.S., Fernandes A.C.S., Ferigolo J. 2007. Preservação e contexto paleoambiental das pegadas de tetrápodes da Formação Santa Maria (Triássico Superior) do Sul do Brasil. In: Congresso Brasileiro de Paleontologia, 20, Paleontologia: Cenários da Vida. Rio de Janeiro, Editora Interciência, p. 525-532.

Silva R.C., Ferigolo F., Carvalho I.S., Fernandes A.C.S. 2008. Lacertoid footprints from the Upper Triassic (Santa Maria Formation) of Southern Brazil. Palaeogeography, Palaeoclimatology, Palaeoecology, 262:140-156.

Swanson B.A. \& Carlson K.J. 2002. Walk, wade or swim? Vertebrate traces on an Early Permian Lakeshore. Palaios, 17:123-133.

Thulborn R. \& Wade M. 1989. A footprint as the history of movement. In: Gillete D.D. \& Lockley M.G. (eds.) Dinosaur tracks and traces. Cambridge University Press, p. 51-56.

Walker R.G. \& Plint A.G. 1992. Wave and storm-dominated shallow marine systems. In: Walker R.G. \& James N.P. (eds.) Facies models-response to sea-level changes. Geological Association of Canada, St. John's, Newfoundland, Canada, p. 219-238.

Williston S.W. 1914. Water Reptiles of the Past and Present. University of Chicago Press, $251 \mathrm{p}$.

Manuscrito ID 14375

Submetido em 19 de maio de 2009 Aceito em 9 de dezembro de 2009 